\title{
Effectiveness of Performance Appraisal System in Large and Medium Size Manufacturing Organisations
}

\author{
${ }^{1} \mathrm{Mr}$ Gaurav Kochhar, ${ }^{2} \mathrm{Dr}$ Bhavet Garg \\ $\left({ }^{I}\right.$ Asst Professor.Maharaja Agrasen Institute of Management and Technology,Jagadhri ,Haryana) \\ ${ }^{2}$ (Associate Professor,Maharishi Markendeshwar University,Mullana Ambala,Haryana)
}

\begin{abstract}
It has now been widely realized that effectiveness of performance appraisal system(PAS) depends on the extent to which the HRD components are a part of the system and how well it is being implemented in practice from the viewpoint of both the appraisers and appraisees.It was emerged form the study that a number of variables in all the three categories (vizPAS design content variables, PAS content variables and PAS outcome variables ) were being taken care of the large extent in the study organizations. However the study also identified many variables (in all the three categories) were being taken care of only to the moderate extent. In the study, it was suggested that the "The moderately taken care of variables "need special attention of the concerned managers in particular and HRD professionals.In general..intercorrelations between the various variables were also established in the study.In depth and empirically tested analysis in this context is being presented in paper
\end{abstract}

Key Words: Appraiser.Appraisee,Career Planning,Employee Satisfaction,Motivation

\section{Introduction}

Human Resources are vital assets for organizational Success. These are to be valued highly for achieving the competitive edge.In this direction, the HR policies and practices should be linked with the organizational goals. The impact of HRM practices can be source for sustained competitive advantage .Enhancement of organizational performance should be the focus for an organization Wright et.al.1999).studies have suggested that training,selection,appraisals,compensation,linking of HRM Practices index to both financial and market outcomes have linkage with organizational Performance (Russel,1985;Terpstraet.al1993; Macduffe,1995;Guest and Hoque,1994;Pfeffer,1994,

Different intangibles assets like customer loyalty, capacity to innovate and change, brand image ,intellectual capital. leadership effectiveness aspects depend heavily on employee's capabilities and commitment. The reality for many organizations is that their human resources remain undervalued,undertrained and underutilized(A.S.Kohli \& T.Deb,2008).Different models on HRM like Hayward Model By Michael Beer(1984),Wheeler and Sillanpa(1997),equally emphasize on the performance outcome of the employees and benefit to all the stakeholders interest including organizational effectiveness. The theoretical treatment provided by Jackson and Schuler(1995) discusses on the role and functional aspects of human resources to help developing the area of Human Resource Management .An Integrated Model on Human Resource Management (A.S.Kohli,2008).It is difficult to trace the true antecedent of formal performance appraisal. But it seems that the performance appraisals of workers on annual basis began with the advent of the industrial revolution in the late Eighteenth century (Kohli, 2008)The basic purpose was to access the the productivity of the worker .The rating of the performance was introduced in the 1920s.The focus of appraisal changed to assessing the personality traits of workers after the Hawthorne studies. And it brought merit rating method for assessing the performance. However the method came under severe criticism as it focused more on the personality traits of workers.Morever traits measures were subjective and dubious in predicting the outcome of an employee(Napier \& Latham,1986).Then MBO approach of appraisal advocated by Peter F. drucker gained popularity.But,too much subjectivity and inconsistency were the limitations of this approach .over time performance management as a concept evolved and gained attention (Beer and Ruh,1976). The real concept of performance management aims for enhancing the performance of both individuals and the organization(Fletcher,1933). And in due course of time many performance management systems like performance pyramid(Cross and Lynch,1991)Balance scorecard (Kaplan \& Norton,1992),Performance Prism(Neeley,2000) have been developed providing a scope for appraising multiple dimensions of performance.

\section{Performance management is $\mathrm{s}$ strategic}

Tool integrated Approach for delivering sustained success to organizations by improving the performance of those who work in them and by developing the capabilities of teams and individual contributors. Development is perhaps the most important function of performance management .Performance improvement is not achievable unless there are effective processes of continuous development. Performance 
management is concerned with outputs-the achievement of results and with outcomes the impact made on performance .But it is also concerned with the process required to achieve these results and the inputs in terms of capabilities (Knowledge,skill and competencies ) expected from the teams and the individuals involved .Effective appraisals begin with defining the job and its standards, however,the job description often isn't sufficient to clarify what you want your subordinates to do, because most are written not for specific jobs but for group for jobs. E

\section{Literature Review}

To get the most out of this resource of people, they must be motivated. However ,Cole(2001) and Wright(2001) argue that people cannot be motivated .Cole and Wright go on to say that people motivate themselves and managers can provide the environment for them to be motivated .There are many ways to provide a motivational environment for employees and these included developing their skills, giving them feedback and rewarding in ways that means something to them .Therefore,performance appraisal can be used as a tool to assist managers in motivating their employees .Performance management includes any management activity aimed at improving performance through training and developing employees, establishing performance standards ,appraising performance, setting performance plans and through managing career and mobility (Matheney,2003).According to Baker (1988) performance appraisal can be most powerful tool that managers have for improving productivity. When designed and used properly, it can assist organizational decisions on reward and promotions, assist employees in their development and career planning and may even increase employees motivation .commitment and satisfaction (Fletcher1993; Wiese and Buckley,1998; Wilson and Western 2001) especially if the performance appraisal process is aligned with the organization stated objectives (wright,2002).However, this alignment tends not be emphasized and as such performance appraisal process is often seen as chore and pointless, judging past performance against targets that are not always clear(Rudman,2003).Further more, when managers felt ill-equipped to conduct effective appraisal it is a task they hate(Pettijohn,Parjer,Pettijohn and kent,2001);Rudman 2003 and performance appraisal is also capable of stirring strong feelings (Fink and longneck ,1998). Sadly as pointed out by Simmons(2003) appositive performance appraisal experience tends to be due to the quality of the personal relationship between manager and employee, where a good relationship creates a good appraisal experience

\section{The Study}

The present study was designed to make an in-depth study of effectiveness of existing performance appraisal system with reference to selected manufacturing organizations. The study was conducted with a view to achieve the following objectives

1) To explore the extent to which the various PAS "Design/Content Variables (DCV)" ,PAS"Process Variables(PV) and PAS "Outcome Variables (OV)" Could be taken care of by the selected organizations

2) To examine the cause and effect relationship of the DCV's PV's and OV's on the overall effectiveness of PAS in the study Organisations

\section{Sampling Design}

\section{Methodology}

The present study was conducted with reference to Ten eight large and medium size manufacturing organizations belonging to private sector located within jurisdiction of Rewari,Gurgaon and Dharuhera in India. The selected organizations represent variety of Industries which manufactures different products belong to different business groups, fall in varying age groups and which also have different levels of profits, employees strength.

The study was mainly based on the cross-section perception analysis of the employees .However ,the study was confined to the perception analysis of the personnel in the managerial cadre, Senior and middle level managers in the role of the appraisers and middle and junior managers in the role of appraises were considered for such analysis.

Out of eleven hundred managers in the population, three hundred seventy senior and middle managers were found to be in the role of appraisers and seven hundred thirty middle and junior managers were found to be in the role of appraisees.Out of three hundred seventy such appraisers one hundred fifty (Fourty percent of population) and out of such seven hundred thirty such appraises four hundred(fifty percent of population ) were selected to respond to two specifically designed and well structured questionnaires as shown in Table -I. out of these two questionnaires one was framed for the appraiser 's response and the other was for appraiser's response .each questionnaire consisted of thirty seven statement with Likert type five point scale. Thirty one independent variable were considered for the study (as shown in Table -ii ) out of which DCV's ,PV;s and OV's were fourteen, eleven and six respectively. The overall effectiveness of the PAS was taken as the Dependent Variable divided into Five variables. 
The tools of statistical analysis consisted of absolute numbers ,mean scores ,comparison of mean scores ,Pearson's Coefficient of Co-rrelation ,multiple regression analysis,ANOVA,t-test and Kolmogrov-Smirnov two sample Test

Table-ICoverage of the Managers (Respondents) in the Sample Survey

\begin{tabular}{|l|l|l|l|l|l|}
\hline Cadre & $\begin{array}{l}\text { Univ } \\
\text { erse }\end{array}$ & $\begin{array}{l}\text { Number Senior and } \\
\text { Middle Level } \\
\text { Managers in the } \\
\text { Role of } \\
\text { Appraisers(Populat } \\
\text { ion Size) }\end{array}$ & $\begin{array}{l}\text { Sample Size of } \\
\text { Appraisers } \\
\text { selected From } \\
\text { the Population }\end{array}$ & $\begin{array}{l}\text { Number of Middle } \\
\text { Level and Junior } \\
\text { Managers in the } \\
\text { Rolae of } \\
\text { Appraises(Population } \\
\text { Size) }\end{array}$ & $\begin{array}{l}\text { Sample Size of } \\
\text { Appraises } \\
\text { selected from } \\
\text { Population }\end{array}$ \\
\hline $\begin{array}{l}\text { Senior Level } \\
\text { Managers }\end{array}$ & 250 & 250 & $100(40 \%)$ & - & - \\
\hline $\begin{array}{l}\text { Middle Level } \\
\text { Managers }\end{array}$ & 250 & 120 & $50(42 \%)$ & 130 & 130 \\
\hline $\begin{array}{l}\text { Junior Level } \\
\text { Managers }\end{array}$ & 600 & - & - & 600 & $270(45 \%)$ \\
\hline Total & 1100 & 370 & $150(40 \%)$ & 730 & $400(54 \%)$ \\
\hline
\end{tabular}

\section{Research Hypothesis}

The following hypothesis have been tested in the present study

(1) All the selected independent variablers are positively correlated to each other

(2) There exists relationships between the effectiveness of PAS with (a) PAS Design/Content Variables ,(b) PAS Process Variables and (c) PAS outcome variables

Table-II List Of Variable Affecting The Overall Effectiveness Of Pas In The Organisation

A. Performance Appraisal System "Design and Content Variables"("DCV")

\begin{tabular}{|l|l|}
\hline DCV-1 & $\begin{array}{l}\text { Employees have clear understanding of what is expected from them regarding their } \\
\text { performance in the organization }\end{array}$ \\
\hline DCV-2 & Performance Appraisal System helps in planning employee's performance well \\
\hline DCV-3 & $\begin{array}{l}\text { Performance Appraisal System provides an opportunity for supportive superior } \\
\text { subordinate communication ,to facilitate the employee's Job Performance }\end{array}$ \\
\hline DCV-4 & $\begin{array}{l}\text { The Performance Appraisal System provides scope for self appraisal and reflection to } \\
\text { the employees }\end{array}$ \\
\hline DCV-5 & $\begin{array}{l}\text { The Performance Appraisal System encourages common understanding between the } \\
\text { superior and the subordinates of the factors affecting the employee's performance }\end{array}$ \\
\hline DCV-6 & $\begin{array}{l}\text { Performance Appraisal System provides an opportunity for discussing the } \\
\text { expectations ,achievements ,failures, constraints and improvements needed between } \\
\text { superiors and the subordinates }\end{array}$ \\
\hline DCV-7 & $\begin{array}{l}\text { Performance Appraisal System provides scope for reflection and assessment of the } \\
\text { employee's personality factors attributes required for their job performance }\end{array}$ \\
\hline DCV-8 & $\begin{array}{l}\text { Performance Appraisal System encourages open communication between superior and } \\
\text { subordinate through performance review discussions }\end{array}$ \\
\hline DCV-9 & $\begin{array}{l}\text { Performance Appraisal system provide scope for employee's expression on their } \\
\text { developmental }\end{array}$ \\
\hline DCV-10 & $\begin{array}{l}\text { Performance Appraisal System provides an opportunity for the redressal of employees } \\
\text { grievances }\end{array}$ \\
\hline DCV-11 & $\begin{array}{l}\text { Performance Appraisal System aims at strengthening mutual understanding and } \\
\text { relationship between superiors and subordinates }\end{array}$ \\
\hline DCV-12 & $\begin{array}{l}\text { Performance Appraisal System helps employees to gain insights into their strengths and } \\
\text { weaknesses }\end{array}$ \\
\hline DCV-13 & $\begin{array}{l}\text { Performance Appraisal helps employees in discovering their potential for preparing } \\
\text { themselves to take up future likely roles of higher level }\end{array}$ \\
\hline DCV-14 & $\begin{array}{l}\text { Performance Appraisal System provides scope for communicating the overall business } \\
\text { goals and plans to the employees }\end{array}$ \\
\hline
\end{tabular}


B .1 Performance Appraisal System "Process Variables"

\begin{tabular}{|l|l|}
\hline PV-1 & $\begin{array}{l}\text { The objectives of performance appraisal system are clear to both superior and } \\
\text { subordinates }\end{array}$ \\
\hline PV-2 & Periodic orientation programmes on Performance Appraisal Systems are conducted \\
\hline PV-3 & Superiors spend time and discuss subordinates performance \\
\hline PV-4 & $\begin{array}{l}\text { Superiors help their performance in planning subordinates performance in the } \\
\text { beginning of the performance period }\end{array}$ \\
\hline PV-5 & $\begin{array}{l}\text { Performance Review discussions on KPA's/KRA's Tasks/Targets are educative to } \\
\text { both superiors and subordinates }\end{array}$ \\
\hline PV-6 & Superiors take performance appraisals seriously \\
\hline PV-7 & $\begin{array}{l}\text { Employees work thoroughly on self appraisal in terms of reviewing ,reflecting and } \\
\text { analyzing the factors affecting their performance }\end{array}$ \\
\hline PV-9 & Superiors devote sufficient time to performance review discussions \\
\hline PV-10 & Performance Review Discussions are of high quality and conducted with care \\
\hline PV-11 & Employees take active part in performance review discussions \\
\hline
\end{tabular}

B2 Performance Appraisal System "Outcomes Variables"("OV”)

\begin{tabular}{|l|l|}
\hline OV-1 & $\begin{array}{l}\text { Superiors and subordinates take corrective actions for improvement based on the } \\
\text { outcome of performance appraisal }\end{array}$ \\
\hline OV-2 & $\begin{array}{l}\text { HRM/HRD/Personnel Department does follow up work on training needs as identified } \\
\text { through appraisals }\end{array}$ \\
\hline OV-3 & $\begin{array}{l}\text { HRM/HRD?Personnel department make use of appraisal data for taking a variety of } \\
\text { developmental; decisions }\end{array}$ \\
\hline OV-4 & $\begin{array}{l}\text { Appraisal Data are used for recognizing and encouraging high performers and desirable } \\
\text { behaviour }\end{array}$ \\
\hline OV-5 & $\begin{array}{l}\text { HRM/HRD/Personnel Department as well as the superiors take employee appraisals } \\
\text { seriously and educate }\end{array}$ \\
\hline OV-6 & $\begin{array}{l}\text { Performance Appraisal System facilitates the growth and learning of both superiors and } \\
\text { subordinates in the organization }\end{array}$ \\
\hline
\end{tabular}

C Dependent variable

\begin{tabular}{|l|l|}
\hline DV & Overall effectiveness of PAS in the study organization \\
\hline DV1 & $\begin{array}{l}\text { Performance Appraisal System promotes Quality Drive in organisation by encouraging } \\
\text { active participation of Employees }\end{array}$ \\
\hline DV2 & Performance Appraisal System promotes High Morale among Employees \\
\hline DV3 & ) Performance Appraisal leads to Improve Task Performance among Employees \\
\hline DV4 & Performance Appraisal Promotes leadership Among Employees \\
\hline DV5 & Performance Appraisal Promotes Learning Among Emplyees \\
\hline
\end{tabular}

TABLE-III Comparative Mean Values Of Appraisers Perception On Variables In Study Organisations Descriptive Statistics

\begin{tabular}{|c|c|c|c|}
\hline & $\mathrm{N}$ & Mean & $\begin{array}{c}\text { Std. } \\
\text { Deviation }\end{array}$ \\
\hline $\begin{array}{l}\text { DCV-1Employees have clear understanding of what is expected from them regarding their } \\
\text { performance in the organization }\end{array}$ & 150 & 3.17 & $\begin{array}{l}1.323 \\
\mathrm{LE}\end{array}$ \\
\hline DCV-2 Performance Appraisal System helps in planning employee's performance well & 150 & 3.17 & $\begin{array}{l}1.325 \\
\mathrm{LE}\end{array}$ \\
\hline $\begin{array}{l}\text { DCV-3 Performance Appraisal System provides an opportunity for supportive superior } \\
\text { subordinate communication to facilitate the employee's job performance }\end{array}$ & 150 & 3.16 & $\begin{array}{c}1.342 \\
\mathrm{LE}\end{array}$ \\
\hline $\begin{array}{l}\text { DCV-4 The Performance Appraisal system provides scope for self Appraisal and reflection in the } \\
\text { employees }\end{array}$ & 150 & 3.00 & $\begin{array}{l}1.390 \\
\mathrm{LE}\end{array}$ \\
\hline $\begin{array}{l}\text { DCV-5 The Performance Appraisal system encourages common understanding(between the } \\
\text { superior and subordinates) of the factors affecting the employee's performance }\end{array}$ & 150 & 2.98 & $\begin{array}{l}1.358 \\
\mathrm{M}\end{array}$ \\
\hline
\end{tabular}


DCV-6 Performance Appraisal System provides an opportunity for discussing the expectations, achievements, failures, constraints and improvements needed between superiors and the subordinates

DCV-7 Performance Appraisal System provides scope for reflection and assessment of the employee's personality factors and attributes required for their job performance

DCV-8 Performance Appraisal System encourages open communication between superior and subordinate through performance review discussions

DCV-9 Performance Appraisal System Provides scope for employee's expression on their development needs

DCV-10 Performance Appraisal System provides an opportunity for the redressal of employee's grievances

DCV-11 Performance Appraisal System aims at strengthening mutual understanding and relationship between superiors and subordinates

DCV-12 Performance Appraisal System helps improves to gain insights into their strengths and weaknesses

DCV-13 Performance Appraisal System helps employees in discovering their potential for preparing themselves to take up future likely roles of higher level

DCV-14 Performance Appraisal System provides scope for communicating the overall business goals and plans to the employees

PV-1The objective of Performance Appraisal System are clear to both superior and subordinates

PV-2 Periodic orientation programmes on Performance Appraisal System are conducted

PV-3Superiors spend time and discuss subordinate performance

PV-4Superiors help their subordinates in planning subordinates performance in the beginning of the performance period

PV-5Performance Review discussions on Key Performance Areas (KPA's)/Key Result

Areas(KRA's)/Tasks/Targets are educative to both superiors and subordinates

PV-6Superiors takes Performance Appraisals seriously

PV-7Employees work thoroughly on self Appraisal in terms of reviewing, reflecting and analyzing the factors affecting their Performance

PV-8Superiors take special efforts to be objective and unbiased while making their comments on subordinate's performance

PV-9Superiors devote sufficient time to performance review discussions

PV-10Performance review discussions are of high quality and conducted with care

PV-11 Employees take active part in performance review discussions

OV-1 Superiors and Subordinates take corrective actions for improvement based on the outcome of Performance Appraisal

OV-2HRM/HRD/Personnel Department does follow up work on training needs as identified through Appraisals

OV-3HRM/HRD/Personnel Department makes use of appraisal data for taking a variety of development decisions

OV-4Appraisal Data are used for recognizing and encouraging high performers and desirable behavior

OV-5HRM/HRD/Personnel Department as well as the superior take employees appraisal seriously and educate them to overcome their personal biases

OV-6Performance Appraisal System facilitates the growth and learning of both superiors and subordinates in the organization

OVERALL EFFECTIVENESS OF PMS-Performance Appraisal System is overall Effective

\begin{tabular}{|c|c|c|}
\hline 150 & 3.05 & $\begin{array}{c}1.338 \\
\mathrm{LE}\end{array}$ \\
\hline 150 & 2.91 & $\begin{array}{c}1.343 \\
\mathrm{M}\end{array}$ \\
\hline 150 & 2.91 & $\begin{array}{c}1.328 \\
\mathrm{M}\end{array}$ \\
\hline 150 & 2.75 & $\begin{array}{c}1.419 \\
\mathrm{M}\end{array}$ \\
\hline 150 & 2.93 & $\begin{array}{c}1.344 \\
\mathrm{M}\end{array}$ \\
\hline 150 & 2.99 & $\begin{array}{c}1.331 \\
\mathrm{M}\end{array}$ \\
\hline 150 & 3.18 & $\begin{array}{c}1.366 \\
\mathrm{LE}\end{array}$ \\
\hline 150 & 3.01 & $\begin{array}{c}1.329 \\
\mathrm{LE}\end{array}$ \\
\hline 150 & 3.00 & $\begin{array}{c}1.336 \\
\text { LE }\end{array}$ \\
\hline 150 & 2.99 & $\begin{array}{c}1.344 \\
\mathrm{M}\end{array}$ \\
\hline 150 & 3.01 & $\begin{array}{c}1.326 \\
\mathrm{LE}\end{array}$ \\
\hline 150 & 2.94 & $\begin{array}{c}1.342 \\
\mathrm{M}\end{array}$ \\
\hline 150 & 2.89 & $\begin{array}{c}1.349 \\
\mathrm{M}\end{array}$ \\
\hline 150 & 2.92 & $\begin{array}{c}1.344 \\
\mathrm{M}\end{array}$ \\
\hline 150 & 2.96 & $\begin{array}{c}1.315 \\
\mathrm{M}\end{array}$ \\
\hline 150 & 2.97 & $\begin{array}{c}1.308 \\
\mathrm{M}\end{array}$ \\
\hline 150 & 2.96 & $\begin{array}{c}1.310 \\
\mathrm{M}\end{array}$ \\
\hline 150 & 2.81 & $\begin{array}{c}1.348 \\
\mathrm{M}\end{array}$ \\
\hline 150 & 2.79 & $\begin{array}{c}1.339 \\
\mathrm{M}\end{array}$ \\
\hline 150 & 2.79 & $\begin{array}{c}1.317 \\
\mathrm{M}\end{array}$ \\
\hline 150 & 2.77 & $\begin{array}{c}1.333 \\
\mathrm{M}\end{array}$ \\
\hline 150 & 2.77 & $\begin{array}{c}1.308 \\
\mathrm{M}\end{array}$ \\
\hline 150 & 2.73 & $\begin{array}{c}1.300 \\
\mathrm{M}\end{array}$ \\
\hline 150 & 2.63 & $\begin{array}{c}1.319 \\
\mathrm{M}\end{array}$ \\
\hline 150 & 2.72 & $\begin{array}{c}1.306 \\
\mathrm{M}\end{array}$ \\
\hline 150 & 2.47 & $\begin{array}{c}1.197 \\
\mathrm{M}\end{array}$ \\
\hline 150 & 2.67 & $\begin{array}{c}1.323 \\
\mathrm{M}\end{array}$ \\
\hline
\end{tabular}

www.iosrjournals.org 
Extent (Mean Scores $>3$ ), M=Medium Extent(Mean scores $>2$ and $<3$ ), Small extent(mean $\operatorname{scores}<2$ )

TABLE-IV Comparative Mean Values Of Appraisee's Perception On Variables In Study Organisations Descriptive Statistics

\begin{tabular}{|c|c|c|c|}
\hline & $\mathrm{N}$ & $\begin{array}{c}\text { Mea } \\
\text { n }\end{array}$ & $\begin{array}{l}\text { Std. } \\
\text { Deviat } \\
\text { ion }\end{array}$ \\
\hline $\begin{array}{l}\text { DCV-1Employees have clear understanding of what is expected from them } \\
\text { regarding their performance in the organization }\end{array}$ & 400 & 3.43 & $\begin{array}{r}1.139 \\
\text { LE }\end{array}$ \\
\hline $\begin{array}{l}\text { DCV-2 Performance Appraisal System helps in planning employee's } \\
\text { performance well }\end{array}$ & 400 & 2.95 & $\begin{array}{r}1.418 \\
\mathrm{M}\end{array}$ \\
\hline $\begin{array}{l}\text { DCV-3 Performance Appraisal System provides an opportunity for supportive } \\
\text { superior subordinate communication to facilitate the employee's job } \\
\text { performance }\end{array}$ & 400 & 2.98 & $\begin{array}{r}1.390 \\
\mathrm{M}\end{array}$ \\
\hline $\begin{array}{l}\text { DCV-4 The Performance Appraisal system provides scope for self Appraisal } \\
\text { and reflection in the employees }\end{array}$ & 400 & 3.05 & $\begin{array}{r}1.358 \\
\text { LE }\end{array}$ \\
\hline $\begin{array}{l}\text { DCV-5 The Performance Appraisal system encourages common } \\
\text { understanding(between the superior and subordinates) of the factors affecting } \\
\text { the employee's performance }\end{array}$ & 400 & 3.06 & $\begin{array}{r}1.347 \\
\text { LE }\end{array}$ \\
\hline $\begin{array}{l}\text { DCV-6 Performance Appraisal System provides an opportunity for discussing } \\
\text { the expectations, achievements, failures, constraints and improvements needed } \\
\text { between superiors and the subordinates }\end{array}$ & 400 & 2.96 & $\begin{array}{r}1.394 \\
\mathrm{M}\end{array}$ \\
\hline $\begin{array}{l}\text { DCV-7 Performance Appraisal System provides scope for reflection and } \\
\text { assessment of the employee's personality factors and attributes required for } \\
\text { their job performance }\end{array}$ & 400 & 2.89 & $\begin{array}{r}1.408 \\
\mathrm{M}\end{array}$ \\
\hline $\begin{array}{l}\text { DCV-8 Performance Appraisal System encourages open communication } \\
\text { between superior and subordinate through performance review discussions }\end{array}$ & 400 & 2.91 & $\begin{array}{r}1.404 \\
\mathrm{M}\end{array}$ \\
\hline $\begin{array}{l}\text { DCV-9 Performance Appraisal System Provides scope for employee's } \\
\text { expression on their development needs }\end{array}$ & 400 & 2.91 & $\begin{array}{r}1.401 \\
\mathrm{M}\end{array}$ \\
\hline $\begin{array}{l}\text { DCV-10 Performance Appraisal System provides an opportunity for the } \\
\text { redressal of employee's grievances }\end{array}$ & 400 & 2.90 & $\begin{array}{r}1.397 \\
\mathrm{M}\end{array}$ \\
\hline $\begin{array}{l}\text { DCV-11 Performance Appraisal System aims at strengthening mutual } \\
\text { understanding and relationship between superiors and subordinates }\end{array}$ & 400 & 2.90 & $\begin{array}{r}1.397 \\
\mathrm{M}\end{array}$ \\
\hline $\begin{array}{l}\text { DCV-12 Performance Appraisal System helps improves to gain insights into } \\
\text { their strengths and weaknesses }\end{array}$ & 400 & 2.90 & $\begin{array}{r}1.392 \\
\mathrm{M}\end{array}$ \\
\hline $\begin{array}{l}\text { DCV13 Performance Appraisal System helps employees in discovering their } \\
\text { potential for preparing themselves to take up future likely roles of higher level }\end{array}$ & 400 & 2.91 & $\begin{array}{r}1.395 \\
\mathrm{M}\end{array}$ \\
\hline $\begin{array}{l}\text { DCV-14 Performance Appraisal System provides scope for communicating } \\
\text { the overall business goals and plans to the employees }\end{array}$ & 400 & 2.91 & $\begin{array}{r}1.411 \\
\mathrm{M}\end{array}$ \\
\hline $\begin{array}{l}\text { PV-1 The objective of Performance Appraisal System are clear to both } \\
\text { superior and subordinates }\end{array}$ & 400 & 2.86 & $\begin{array}{r}1.414 \\
\mathrm{M}\end{array}$ \\
\hline $\begin{array}{l}\text { PV-2 Periodic orientation programmes on Performance Appraisal System are } \\
\text { conducted }\end{array}$ & 400 & 2.85 & $\begin{array}{r}1.409 \\
\mathrm{M}\end{array}$ \\
\hline PV-3 Superiors spend time and discuss subordinate performance & 400 & 2.86 & $\begin{array}{r}1.410 \\
\mathrm{M}\end{array}$ \\
\hline $\begin{array}{l}\text { PV-4 Superiors help their subordinates in planning subordinates performance } \\
\text { in the beginning of the performance period }\end{array}$ & 400 & 2.86 & $\begin{array}{r}1.412 \\
\mathrm{M}\end{array}$ \\
\hline
\end{tabular}


PV-5 Performance Review discussions on Key Performance Areas

(KPA's)/Key Result Areas(KRA's)/Tasks/Targets are educative to both

superiors and subordinates

PV-6Superiors takes Performance Appraisals seriously

PV-7 Employees work thoroughly on self Appraisal in terms of reviewing, reflecting and analyzing the factors affecting their Performance

PV-8Superiors take special efforts to be objective and unbiased while making their comments on subordinate's performance

PV-9Superiors devote sufficient time to performance review discussions

PV-10 Performance review discussions are of high quality and conducted with care

PV-11 Employees take active part in performance review discussions

OV-1 Superiors and Subordinates take corrective actions for improvement based on the outcome of Performance Appraisal

OV-2 HRM/HRD/Personnel Department does follow up work on training

needs as identified through Appraisals

OV-3 HRM/HRD/Personnel Department makes use of appraisal data for taking a variety of development decisions

OV-4 Appraisal Data are used for recognizing and encouraging high

performers and desirable behavior

OV-5 HRM/HRD/Personnel Department as well as the superior take

employees appraisal seriously and educate them to overcome their personal biases

OV-6 Performance Appraisal System facilitates the growth and learning of both superiors and subordinates in the organization

OVERALL EFFECTIVENESS OF PMS- Performance Appraisal System is overall Effective

Valid N (list wise)

\begin{tabular}{|c|c|c|}
\hline 400 & 2.84 & $\begin{array}{r}1.413 \\
\mathrm{M}\end{array}$ \\
\hline 00 & 2.84 & $\begin{array}{r}1.410 \\
\mathrm{M}\end{array}$ \\
\hline 0 & 2.88 & $\begin{array}{r}1.386 \\
\mathrm{M}\end{array}$ \\
\hline 0 & 2.90 & $\begin{array}{r}1.344 \\
\mathrm{M}\end{array}$ \\
\hline 400 & 2.83 & $\begin{array}{r}1.373 \\
\mathrm{M}\end{array}$ \\
\hline 400 & 2.84 & $\begin{array}{r}1.367 \\
\mathrm{M}\end{array}$ \\
\hline 00 & 2.89 & $\begin{array}{r}1.355 \\
\mathrm{M}\end{array}$ \\
\hline 400 & 2.87 & $\begin{array}{r}1.348 \\
\mathrm{M}\end{array}$ \\
\hline 400 & 2.86 & $\begin{array}{r}1.350 \\
\mathrm{M}\end{array}$ \\
\hline 400 & 2.89 & $\begin{array}{r}1.360 \\
\mathrm{M}\end{array}$ \\
\hline 400 & 2.86 & $\begin{array}{r}1.358 \\
\mathrm{M}\end{array}$ \\
\hline 400 & 2.86 & $\begin{array}{r}1.372 \\
\mathrm{M}\end{array}$ \\
\hline 400 & 2.85 & $\begin{array}{r}1.384 \\
\mathrm{M}\end{array}$ \\
\hline 400 & 2.90 & $\begin{array}{r}1.345 \\
\mathrm{M}\end{array}$ \\
\hline 400 & & \\
\hline
\end{tabular}

Extent (Mean Scores $>3$ ),M=Medium Extent(Mean scores $>2$ and $<3$ ),Small extent(mean scores $<2$ )

\section{Results}

1) Both appraisers and appraises perceived (as shown in Table-III and Table-IV) that the following two PAS variables (DCV) were found to be part of PAS to a large extent in the study organizations

(a) Employees have clear understanding of what is expected form them regarding their performance in the organization $(\mathrm{DCV}-1)$ (Appraisers mean score $=3.17$,appraisee's mean score $=3.43$ )

(b) The PAS provides scope for self appraisal and reflection to the employees (DCV-4)(Appraiser's mean score $=3.00$ and appraisee's mean score $=3.05$ )

TABLE-V CORRELATION OF THE APPRAISER

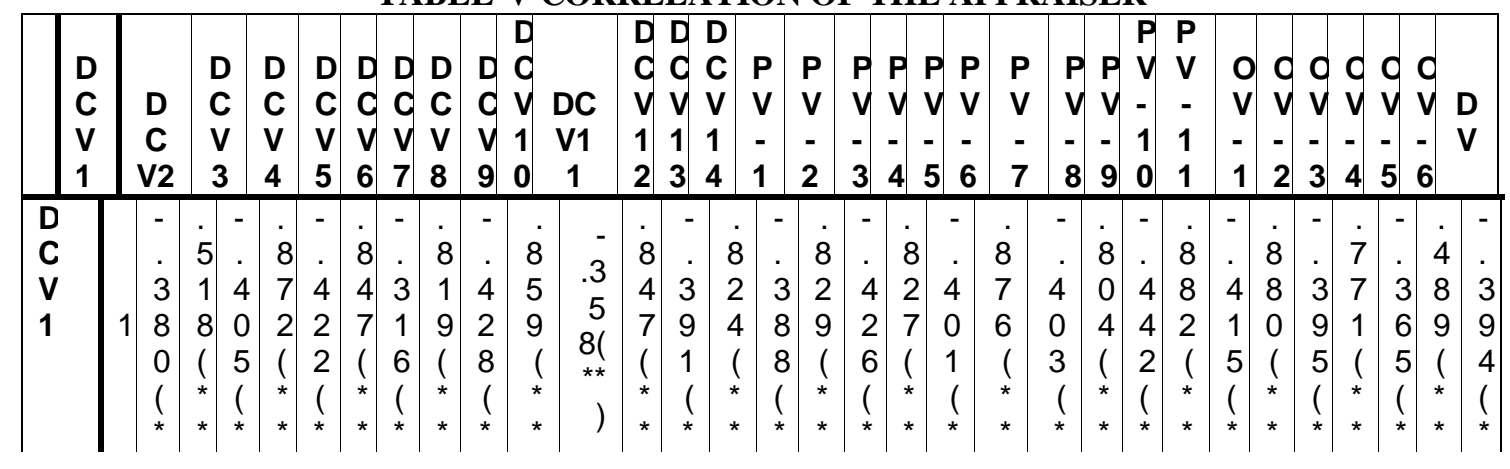




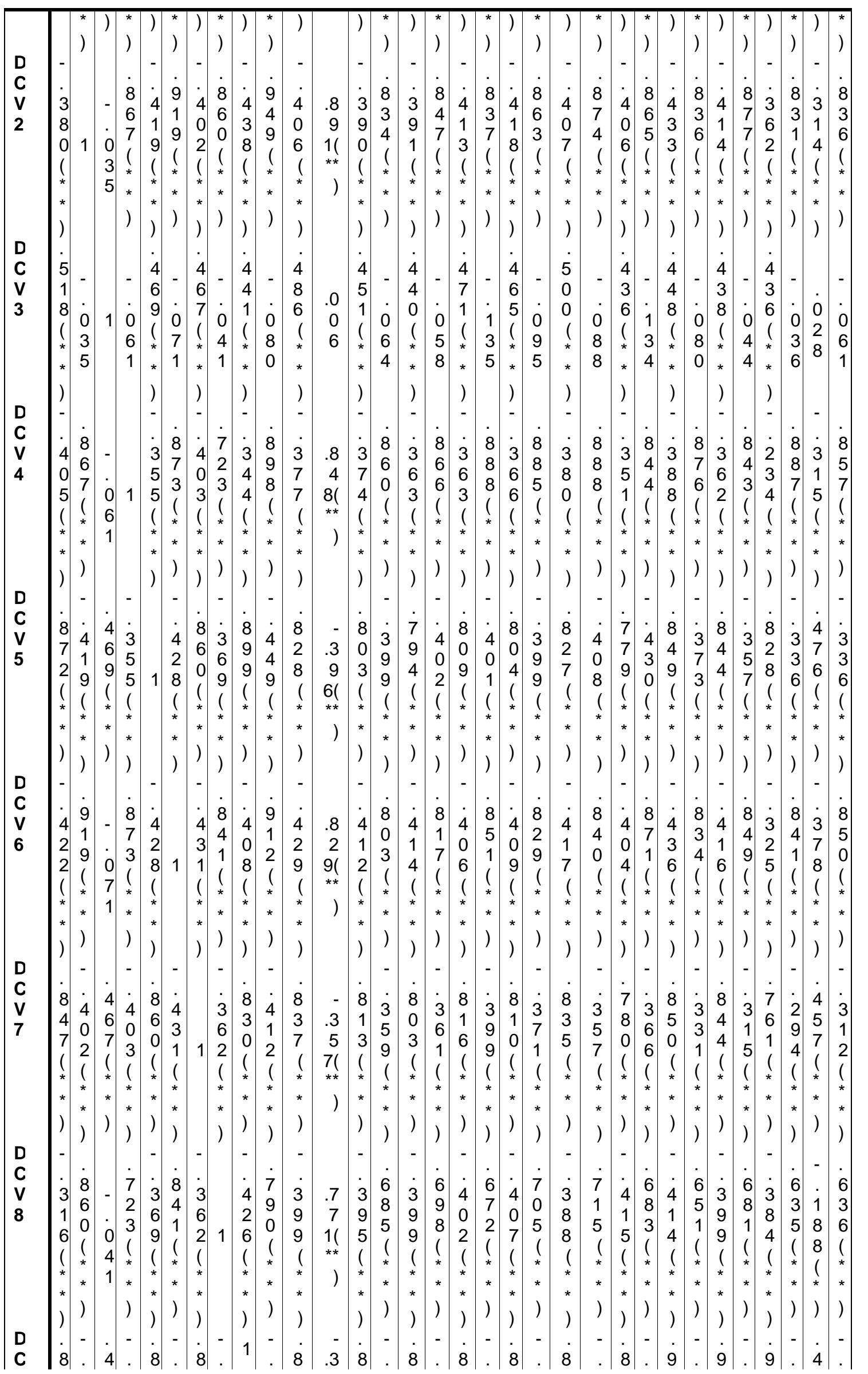




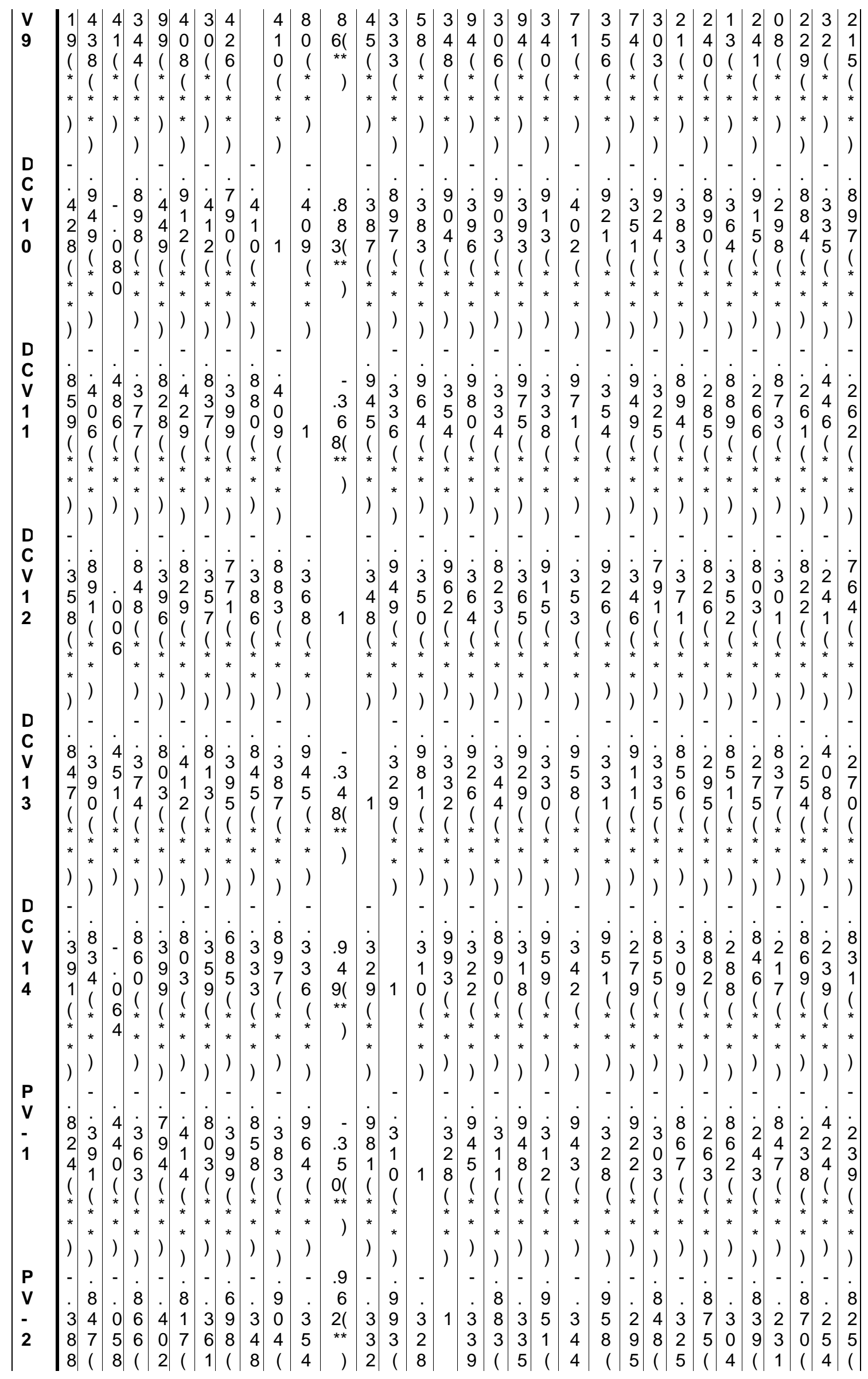




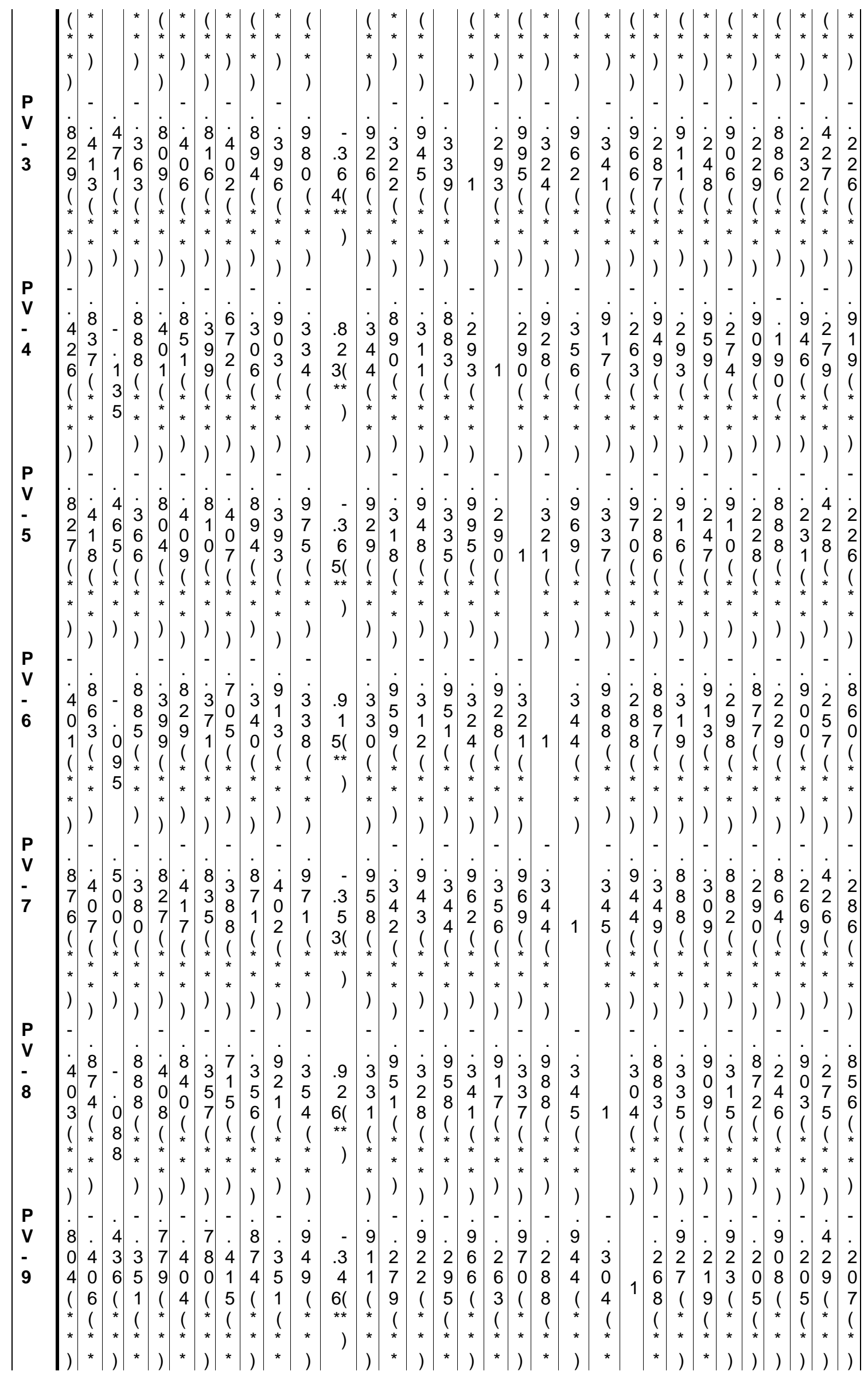




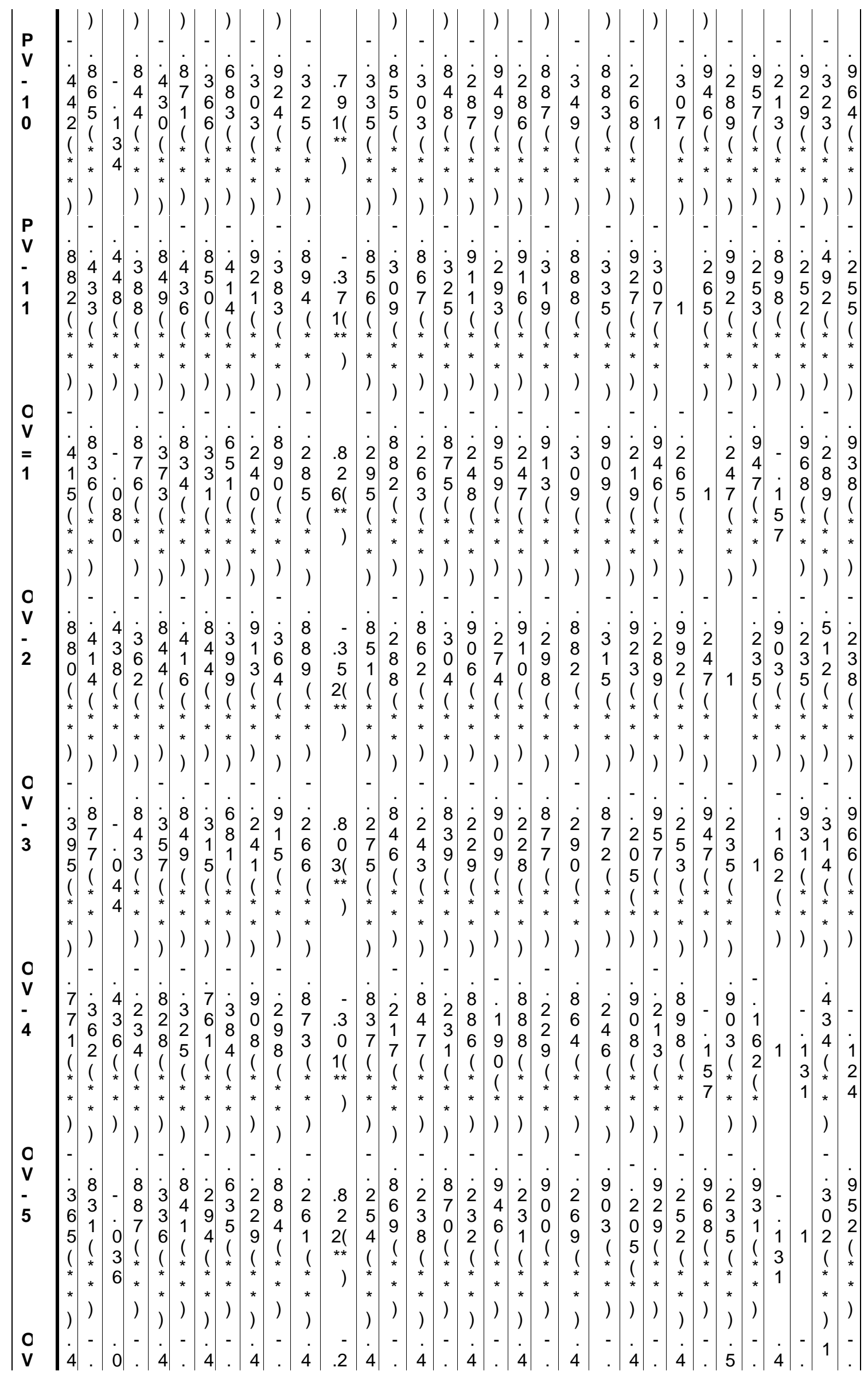




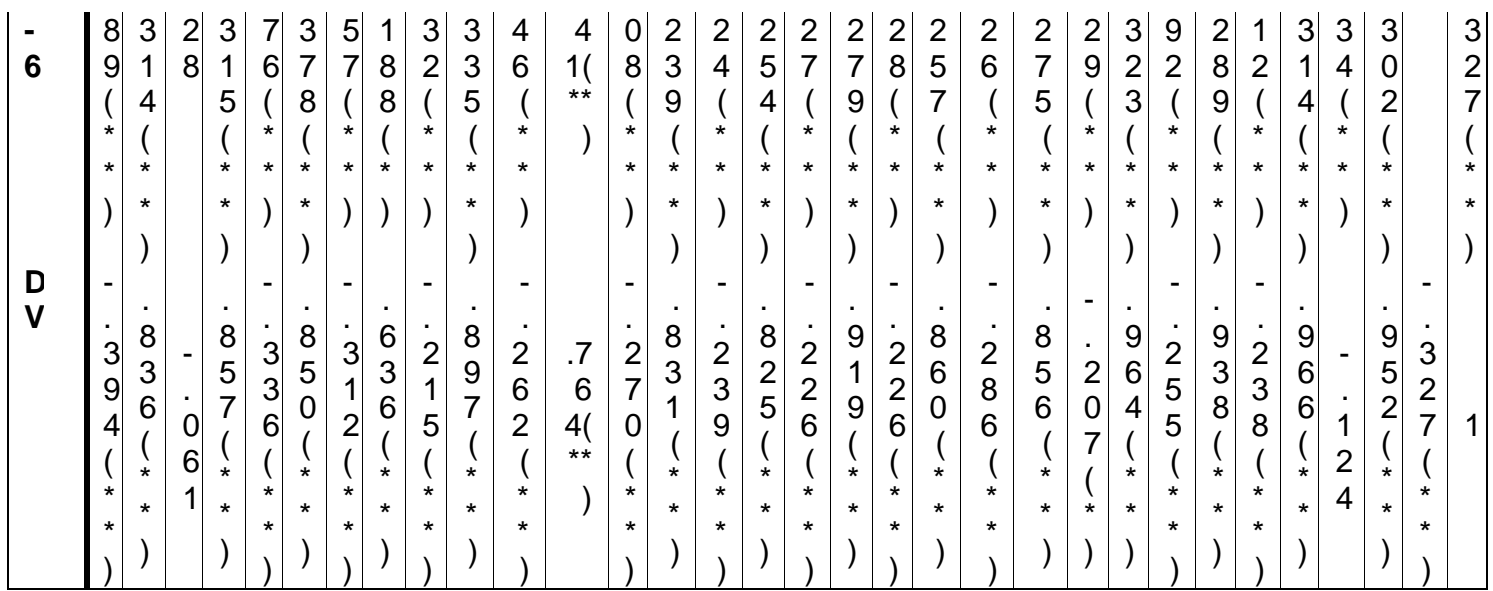

** Correlation is significant at the 0.01 level (2-tailed).

* Correlation is significant at the 0.05 level (2-tailed).

TABLE-VI-CORRELATIONS OF APPRISEE

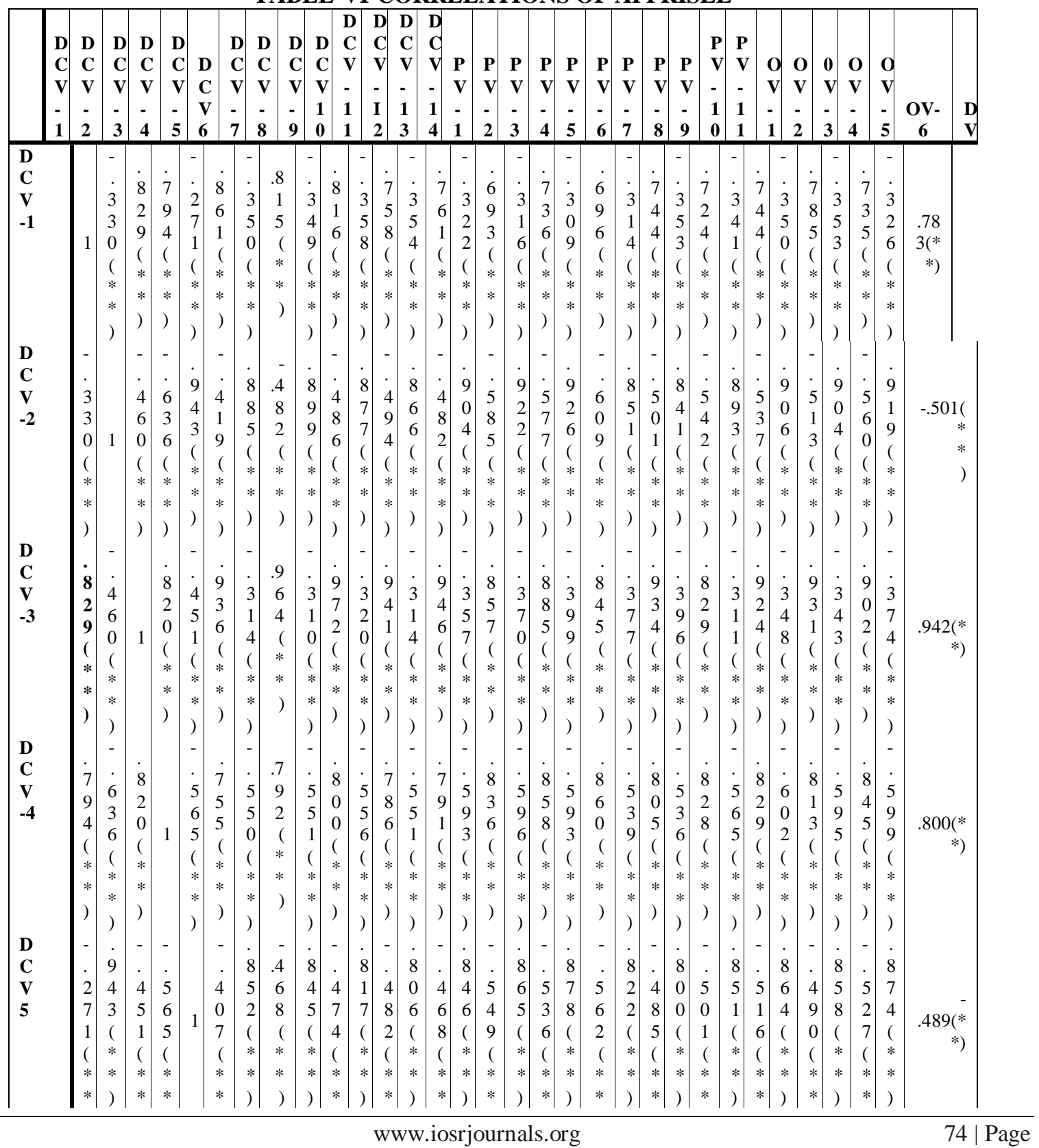




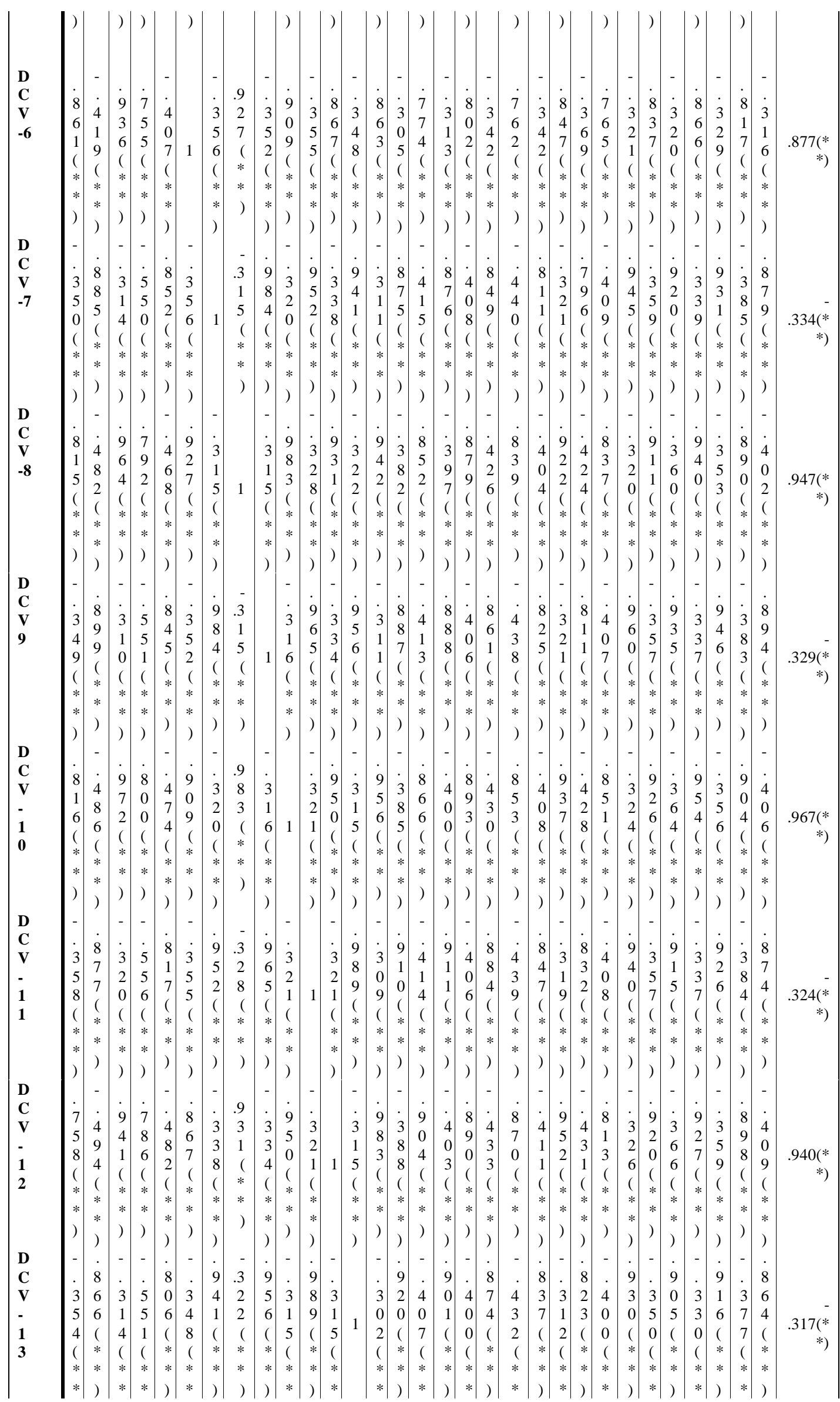




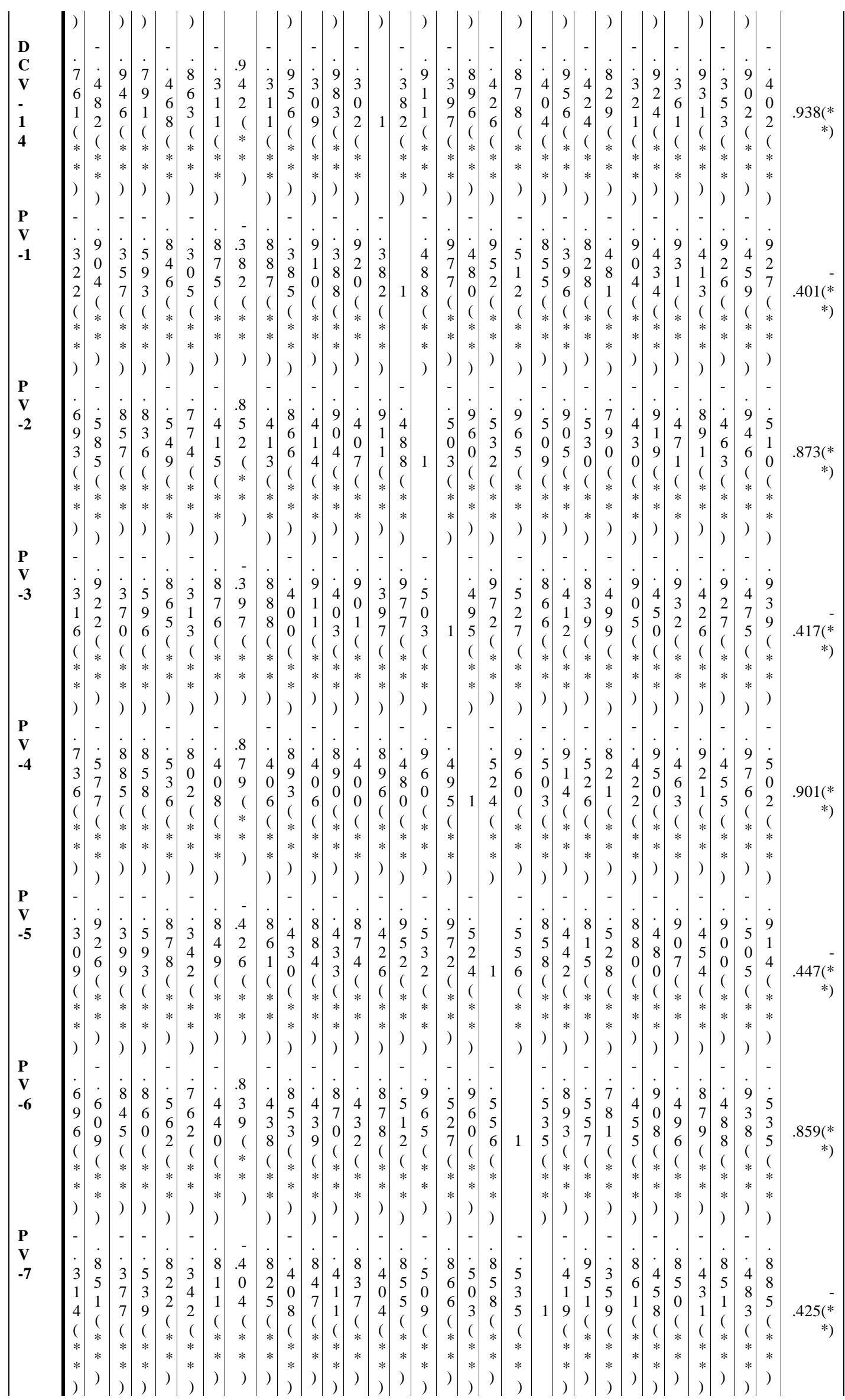




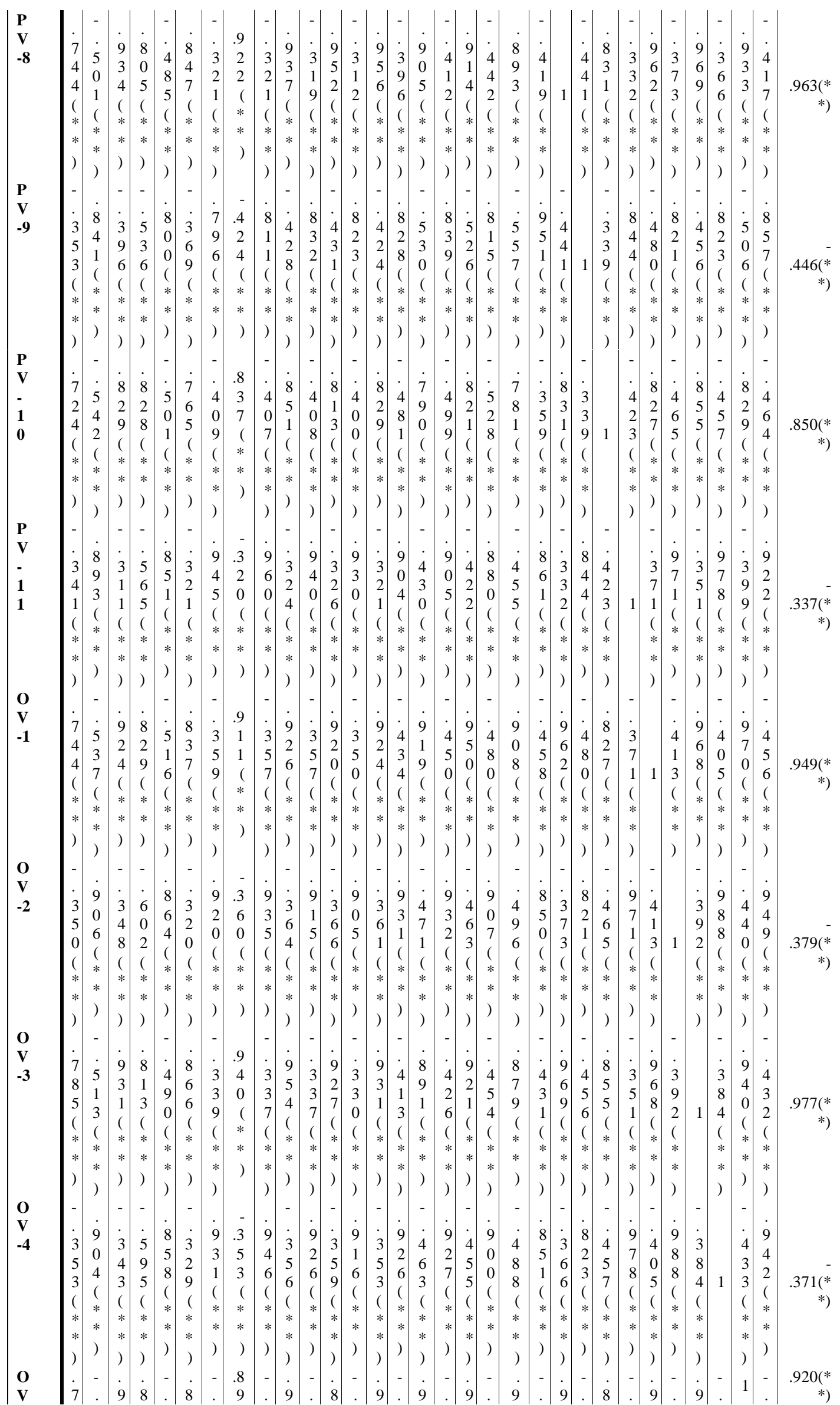




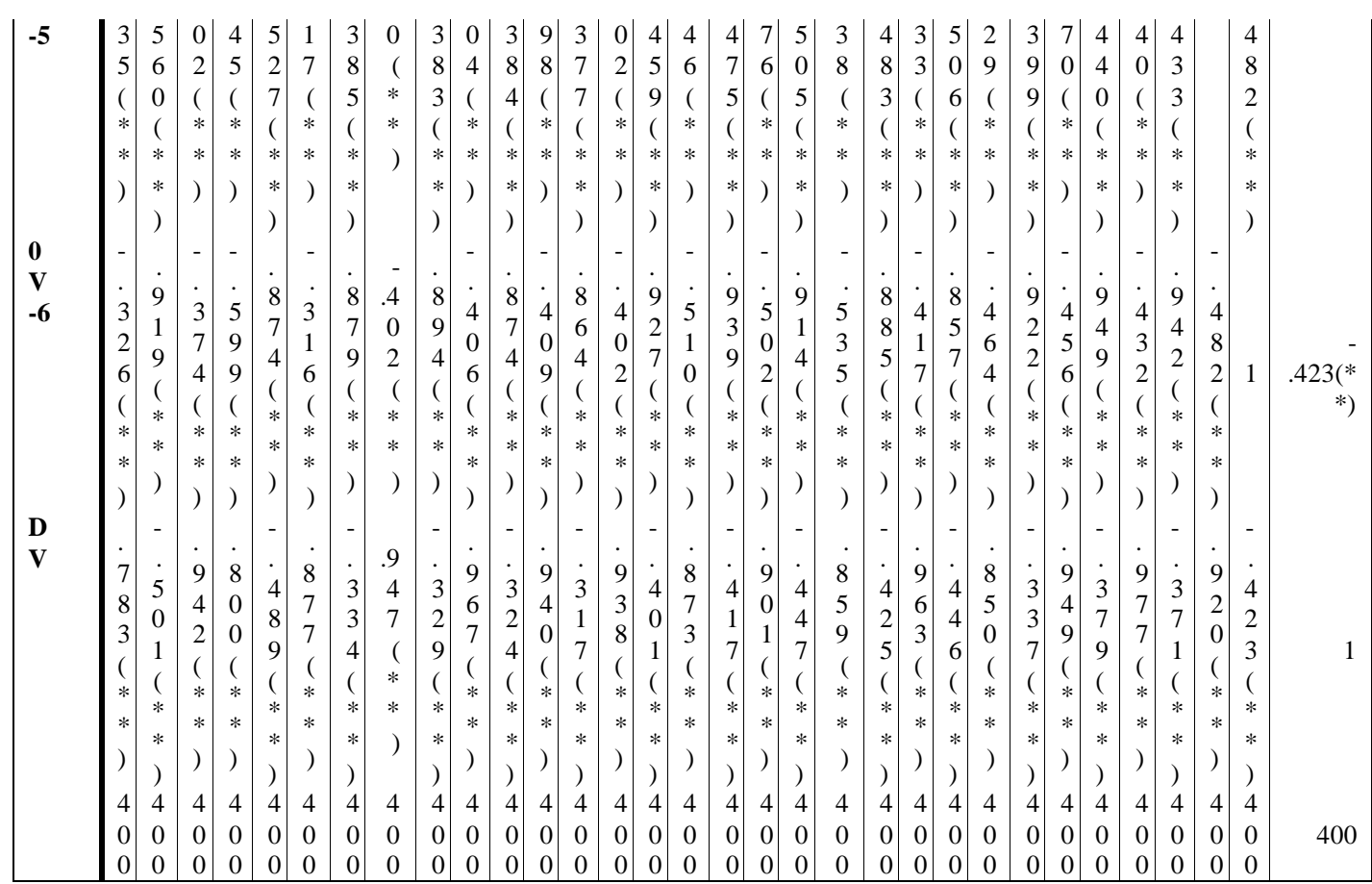

** Correlation is significant at the 0.01 level (2-tailed).

TABLE-VII-A-Relationship between the PAS Design/Content Variables and the overall effectiveness of Regression-APPRAISER PAS

\begin{tabular}{|c|c|c|c|}
\hline \multicolumn{4}{|c|}{ Variables Entered/Removed } \\
\hline Model & $\begin{array}{c}\text { Variables } \\
\text { Entered }\end{array}$ & $\begin{array}{l}\text { Variables } \\
\text { Removed }\end{array}$ & Method \\
\hline 1 & $\mathrm{DCV}^{\mathrm{a}}$ & & Enter \\
\hline
\end{tabular}

a. All requested $v$ ariables entered.

b. Dependent Variable: OVERALL

\begin{tabular}{|l|r|r|r|r|}
\multicolumn{7}{c|}{ Model Summary } \\
\hline Model & $R$ & R Square & $\begin{array}{c}\text { Adjusted } \\
\text { R Square }\end{array}$ & $\begin{array}{c}\text { Std. Error of } \\
\text { the Estimate }\end{array}$ \\
\hline 1 & $.934^{\mathrm{a}}$ & .873 & .872 & 4.91080 \\
\hline
\end{tabular}

a. Predictors: (Constant), DCV

ANOV Ab

\begin{tabular}{|ll|r|r|r|r|r|}
\hline Model & & \multicolumn{1}{c|}{$\begin{array}{c}\text { Sum of } \\
\text { Squares }\end{array}$} & df & Mean Square & \multicolumn{1}{c|}{ F } & Sig. \\
\hline 1 & Regression & 24481.304 & 1 & 24481.304 & 1015.150 & $.000^{\mathrm{a}}$ \\
& Residual & 3569.162 & 148 & 24.116 & & \\
& Total & 28050.465 & 149 & & & \\
\hline
\end{tabular}

a. Predictors: (Constant), DCV

b. Dependent Variable: OVERALL

Coefficients

\begin{tabular}{|c|c|c|c|c|c|c|}
\hline \multirow{2}{*}{\multicolumn{2}{|c|}{ Model }} & \multicolumn{2}{|c|}{$\begin{array}{c}\text { Unstandardized } \\
\text { Coefficients }\end{array}$} & \multirow{2}{*}{$\begin{array}{l}\text { Standardized } \\
\text { Coeff icients } \\
\text { Beta }\end{array}$} & \multirow[b]{2}{*}{$\mathrm{t}$} & \multirow[b]{2}{*}{ Sig. } \\
\hline & & $\mathrm{B}$ & Std. Error & & & \\
\hline & (Constant) & -.794 & 1.869 & & -.425 & .672 \\
\hline & DCV & .965 & .030 & .934 & 31.861 & .000 \\
\hline
\end{tabular}

a. Dependent Variable: OVERALL 
TABLE-VII-B-Relationship between the PAS Process Variables and the overall effectiveness of the PAS

Variables Entered/Removed

\begin{tabular}{|l|l|l|l|}
\hline Model & $\begin{array}{c}\text { Variables } \\
\text { Entered }\end{array}$ & $\begin{array}{c}\text { Variables } \\
\text { Removed }\end{array}$ & Method \\
\hline 1 & $\mathrm{PV}^{\mathrm{a}}$ & & Enter \\
\hline
\end{tabular}

a. All requested $v$ ariables entered.

b. Dependent Variable: OVERALL

Model Summary

\begin{tabular}{|l|r|r|r|r|}
\hline Model & $\mathrm{R}$ & $\mathrm{R}$ Square & $\begin{array}{c}\text { Adjusted } \\
\text { R Square }\end{array}$ & $\begin{array}{c}\text { Std. Error of } \\
\text { the Estimate }\end{array}$ \\
\hline 1 & $.957^{\mathrm{a}}$ & .916 & .915 & 3.99224 \\
\hline
\end{tabular}

a. Predictors: (Constant), PV

ANOVA ${ }^{b}$

\begin{tabular}{|c|c|c|c|c|c|c|}
\hline Model & & $\begin{array}{l}\text { Sum of } \\
\text { Squares }\end{array}$ & df & Mean Square & $\mathrm{F}$ & Sig. \\
\hline 1 & $\begin{array}{l}\text { Regression } \\
\text { Residual } \\
\text { Total }\end{array}$ & $\begin{array}{r}25691.646 \\
2358.819 \\
28050.465\end{array}$ & $\begin{array}{r}1 \\
148 \\
149\end{array}$ & $\begin{array}{r}25691.646 \\
15.938\end{array}$ & 1611.978 & $.000^{\mathrm{a}}$ \\
\hline
\end{tabular}

a. Predictors: (Constant), PV

b. Dependent Variable: OVERALL

Coefficients

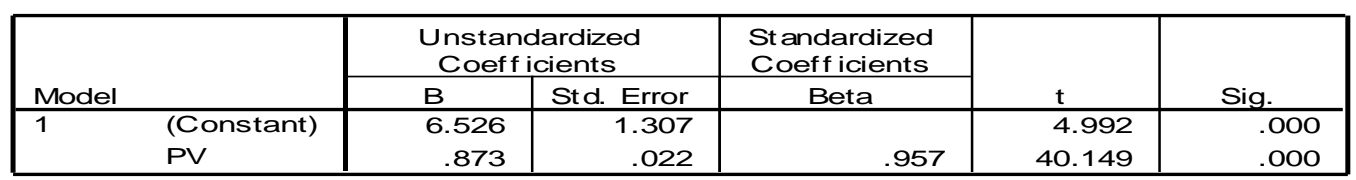

a. Dependent Variable: OVERALL

TABLE-VII-C-Relationship between the PAS outcome variables and overall effectiveness of PAS

Variables Entered/Removed

\begin{tabular}{|l|l|l|l|}
\hline Model & $\begin{array}{c}\text { Variables } \\
\text { Entered }\end{array}$ & $\begin{array}{c}\text { Variables } \\
\text { Removed }\end{array}$ & Method \\
\hline 1 & $\mathrm{OV}^{a}$ & & Enter \\
\hline
\end{tabular}

a. All requested $v$ ariables entered.

b. Dependent Variable: OVERALL

Model Summary

\begin{tabular}{|l|r|r|r|r|}
\hline Model & $\mathrm{R}$ & $\mathrm{R}$ Square & $\begin{array}{c}\text { Adjusted } \\
\text { R Square }\end{array}$ & $\begin{array}{c}\text { Std. Error of } \\
\text { the Estimate }\end{array}$ \\
\hline 1 & $.941^{\mathrm{a}}$ & .886 & .885 & 4.64526 \\
\hline
\end{tabular}

a. Predictors: (Constant), OV

\begin{tabular}{|c|c|c|c|c|c|c|}
\hline \multicolumn{7}{|c|}{ ANOVA } \\
\hline Model & & $\begin{array}{l}\text { Sum of } \\
\text { Squares }\end{array}$ & df & Mean Square & $\mathrm{F}$ & Sig. \\
\hline 1 & $\begin{array}{l}\text { Regression } \\
\text { Residual } \\
\text { Total }\end{array}$ & $\begin{array}{r}24856.852 \\
3193.613 \\
28050.465\end{array}$ & $\begin{array}{r}1 \\
148 \\
149\end{array}$ & $\begin{array}{r}24856.852 \\
21.578\end{array}$ & 1151.929 & $.000^{\mathrm{a}}$ \\
\hline
\end{tabular}

a. Predictors: (Constant), OV

b. Dependent Variable: OVERALL 
Coeffici ents

\begin{tabular}{|c|c|c|c|c|c|c|}
\hline \multirow{2}{*}{\multicolumn{2}{|c|}{ Model }} & \multicolumn{2}{|c|}{$\begin{array}{c}\text { Unstandardized } \\
\text { Coeff icients }\end{array}$} & \multirow{2}{*}{$\begin{array}{l}\text { St andardized } \\
\text { Coefficients } \\
\text { Beta }\end{array}$} & \multirow[b]{2}{*}{$t$} & \multirow[b]{2}{*}{ Sig. } \\
\hline & & $\mathrm{B}$ & Std. Error & & & \\
\hline & $\begin{array}{l}\text { (Constant) } \\
\text { OV }\end{array}$ & $\begin{array}{r}11.986 \\
.847\end{array}$ & $\begin{array}{r}1.390 \\
.025\end{array}$ & .941 & $\begin{array}{r}8.624 \\
33.940\end{array}$ & $\begin{array}{l}.000 \\
.000\end{array}$ \\
\hline
\end{tabular}

a. Dependent Variable: OVERALL

2. Both appraisers and appraisees perceived (as shown in Table-III AND IV) That the following two PAS process variables $(\mathrm{PV})$ were found to be followed by the employees in the process of PAS to Medium Extent in the study organizations.

(a) Employees work thoroughly on self appraisal in terms orf reviewing, reflecting and analyzing the factors affecting their performance(PV-7)(Appraiser's and Appraisee's mean score>2 and <3)

(b) Employees taker active part in performance review discussions(PV-11)(Appraiser's and Appraise's mean score $>2$ and $<3$ )

3 Both the appraisers and appraisees perceived (as shown in the Table-III AND TABLE -IV) that one PAS outcome variable(OV), viz HRM(HRD) Personnel Department does follow up work on Training needs as identified through appraisals(Appraisers and appraisees mean score $>2$ and $<3$ ) was found to be taken care to a medium extent in the study organization

4 Both the appraisers and the appraisees perceived that the PAS Design/Content variables (viz ,DCV-7,DCV9,DCV-10,DCV-11,)(Reference: Table II for full version of these variables) were found to be part of the performance appraisal system to the moderate extent in the study organizations.

5 both the appraisers and the appraisees perceived that the PAS process variables (viz PV-1,PV-4 and PV5)(Reference:TableII for full version of these variables) were found to be part of performance appraisal system to the moderate extent in the study organizations.

6 Both the appraiser and the appraisees perceived that the PAS outcome variables (Viz.OV-3,OV-4 And OV5)(Reference:TableII for full version of these variables) were found to be taken care to the moderate extent in the study organizations

Regression

Variables Entered/Remo ved
\begin{tabular}{|l|l|l|l|}
\hline Model & $\begin{array}{c}\text { Variables } \\
\text { Entered }\end{array}$ & $\begin{array}{c}\text { Variables } \\
\text { Removed }\end{array}$ & Method \\
\hline 1 & DCV $^{\text {a }}$ & & Enter \\
\hline
\end{tabular}

a. All requested $v$ ariables entered.

b. Dependent Variable: OVER ALL (pas)

Model Summary

\begin{tabular}{|l|r|r|r|r|}
\hline Model & $\mathrm{R}$ & $\mathrm{R}$ Square & $\begin{array}{c}\text { Adjusted } \\
\mathrm{R} \text { Square }\end{array}$ & $\begin{array}{c}\text { Std. Error of } \\
\text { the Estimate }\end{array}$ \\
\hline 1 & $.978^{\mathrm{a}}$ & .957 & .957 & 2.78143 \\
\hline
\end{tabular}

a. Predictors: (Constant), DCV

\begin{tabular}{|c|c|c|c|c|c|c|}
\hline \multicolumn{7}{|c|}{ ANOVA $A^{b}$} \\
\hline Model & & $\begin{array}{l}\text { Sum of } \\
\text { Squares }\end{array}$ & $d f$ & Mean Square & $\mathrm{F}$ & Sig. \\
\hline 1 & $\begin{array}{l}\text { Regression } \\
\text { Residual } \\
\text { Total }\end{array}$ & $\begin{array}{r}68877.866 \\
3079.068 \\
71956.934\end{array}$ & $\begin{array}{r}1 \\
398 \\
399\end{array}$ & $\begin{array}{r}68877.866 \\
7.736\end{array}$ & 8903.147 & $.000^{a}$ \\
\hline
\end{tabular}

a. Predictors: (Constant), DCV

b. Dependent Variable: OVER ALL (pas)

Coefficients

\begin{tabular}{|c|c|c|c|c|c|c|}
\hline \multirow{2}{*}{\multicolumn{2}{|c|}{ Model }} & \multicolumn{2}{|c|}{$\begin{array}{l}\text { Unstandardized } \\
\text { Coeff icients }\end{array}$} & \multirow{2}{*}{$\begin{array}{l}\text { Standardized } \\
\text { Coeff icients } \\
\text { Beta }\end{array}$} & \multirow[b]{2}{*}{$t$} & \multirow[b]{2}{*}{ Sig. } \\
\hline & & B & Std. Error & & & \\
\hline 1 & (Constant) & 3.270 & .599 & & 5.460 & .000 \\
\hline & DCV & .924 & .010 & .978 & 94.356 & .000 \\
\hline
\end{tabular}

a. Dependent Variable: OVER AШ (pas) 


\section{Regression}

Variables Entered/Removed
\begin{tabular}{|l|l|l|l|}
\hline Model & $\begin{array}{c}\text { Variables } \\
\text { Entered }\end{array}$ & $\begin{array}{c}\text { Variables } \\
\text { Removed }\end{array}$ & Method \\
\hline 1 & PV $^{\text {a }}$ & & Enter \\
\hline
\end{tabular}

a. All requested $v$ ariables entered.

b. Dependent Variable: OVER ALL (pas)

Model Summary

\begin{tabular}{|l|r|r|r|r|}
\hline Model & $\mathrm{R}$ & $\mathrm{R}$ Square & $\begin{array}{c}\text { Adjusted } \\
\mathrm{R} \text { Square }\end{array}$ & $\begin{array}{c}\text { Std. Error of } \\
\text { the Estimate }\end{array}$ \\
\hline 1 & $.947^{\mathrm{a}}$ & .897 & .897 & 4.30663 \\
\hline
\end{tabular}

a. Predictors: (Constant), PV

\begin{tabular}{|c|c|c|c|c|c|c|}
\hline \multicolumn{7}{|c|}{ ANOVA $A^{b}$} \\
\hline Model & & $\begin{array}{l}\text { Sum of } \\
\text { Squares }\end{array}$ & $d f$ & Mean Square & $\mathrm{F}$ & Sig. \\
\hline 1 & $\begin{array}{l}\text { Regression } \\
\text { Residual } \\
\text { Total }\end{array}$ & $\begin{array}{r}64575.190 \\
7381.743 \\
71956.934\end{array}$ & $\begin{array}{r}1 \\
398 \\
399\end{array}$ & $\begin{array}{r}64575.190 \\
18.547\end{array}$ & 3481.688 & $.000^{a}$ \\
\hline
\end{tabular}

a. Predictors: (Constant), PV

b. Dependent Variable: OVER ALL (pas)

Coefficients

\begin{tabular}{|rl|r|r|r|r|r|}
\hline \multirow{2}{*}{ Model } & \multicolumn{2}{|c|}{$\begin{array}{c}\text { Unstandardized } \\
\text { Coeff icients }\end{array}$} & \multicolumn{2}{c|}{$\begin{array}{c}\text { Standardized } \\
\text { Coeff icients }\end{array}$} & \\
\cline { 2 - 5 } & & \multicolumn{1}{|c|}{ B } & Std. Error & Beta & \multicolumn{1}{c|}{ t } & Sig. \\
\hline 1 & (Constant) & 2.772 & .964 & & 2.874 & .004 \\
& PV & .970 & .016 & .947 & 59.006 & .000 \\
\hline
\end{tabular}

a. Dependent Variable: OVER AШ (pas)

\section{Regression}

Variables Entered/Removed
\begin{tabular}{|l|l|c|l|}
\hline Model & $\begin{array}{c}\text { Variables } \\
\text { Entered }\end{array}$ & $\begin{array}{c}\text { Variables } \\
\text { Removed }\end{array}$ & Method \\
\hline 1 & OV $^{\text {a }}$ & & Enter \\
\hline
\end{tabular}

a. All requested $v$ ariables entered.

b. Dependent Variable: OVER ALL (pas)

\begin{tabular}{|l|r|r|r|r|}
\multicolumn{7}{c|}{ Model Summary } \\
\hline Model & $\mathrm{R}$ & $\mathrm{R}$ Square & $\begin{array}{c}\text { Adjusted } \\
\text { R Square }\end{array}$ & $\begin{array}{c}\text { Std. Error of } \\
\text { the Estimate }\end{array}$ \\
\hline 1 & $.961^{\mathrm{a}}$ & .924 & .924 & 3.70443 \\
\hline
\end{tabular}

a. Predictors: (Constant), OV

ANOVA

\begin{tabular}{|ll|r|r|r|r|r|}
\hline Model & & Sum of & & & & \\
\hline 1 & Squares & df & Mean Square & F & Sig. \\
\hline & Regression & 66495.262 & 1 & 66495.262 & 4845.607 & $.000^{\mathrm{a}}$ \\
& Residual & 5461.671 & 398 & 13.723 & & \\
& Total & 71956.934 & 399 & & & \\
\hline
\end{tabular}

a. Predictors: (Constant), OV

b. Dependent Variable: OVER ALL (pas) 


\section{Coefficients}

\begin{tabular}{|c|c|c|c|c|c|c|}
\hline \multirow{2}{*}{\multicolumn{2}{|c|}{ Model }} & \multicolumn{2}{|c|}{$\begin{array}{l}\text { Unstandardized } \\
\text { Coeff icients }\end{array}$} & \multirow{2}{*}{$\begin{array}{l}\text { St andardized } \\
\text { Coefficients } \\
\text { Beta }\end{array}$} & \multirow[b]{2}{*}{$\mathrm{t}$} & \multirow[b]{2}{*}{ Sig. } \\
\hline & & $\mathrm{B}$ & Std. Error & & & \\
\hline & (Constant) & 7.516 & .752 & & 9.997 & .000 \\
\hline & OV & .883 & .013 & .961 & 69.610 & .000 \\
\hline
\end{tabular}

a. Dependent Variable: OVER ALL (pas)

7 None of the PAS Design/ content variables (DCV),PAS process variables (PV) and PAS outcome variables (OV) were perceived by the appraisers and appraisees to be taken care to small (low) extent

8 Except a few variables as seen from Table -V and Table-VI ,the PAS Design/Content variables ,PAS process variables and PAS Process Variables and PAS Outcome Variables were found to be positive and significantly correlated (at=.01) with each other. Therefore the first hypothesis stating" All the selected independent variables are positively correlated to each other ".is by and large accepted

9 The relationship between PAS process variable viz (i) "Supervisors take performance appraisals seriously" (PV-8) and (ii) "Performance Review discussions are of high quality and conducted with care"(PV-9) was found to be high and positively correlated ( $\mathrm{r}=0.951)$

10 It is observed from Tables VII A That PAS Design/Content Variables were found to be high and positively correlated $(\mathrm{r} 2=0.957)$ to the overall effectiveness of the performance appraisal system in the study organizations. It is further revealed that the relationship is significant (at 0.01 or .o5).Significant impact of the following PAS Design/Content variables were found to be there on the overall effectiveness of PAS viz DCV2,DCV-4,DCV-5,DCV-6,DCV-8,DCV-9,DCV-10,DCV-11,DCV-12 and DCV-13 (Reference: Table-ii for full version of these variables )

11 It is found form Tables VIIB that PAS Process variables have high and positive correlation (r2 $=0.897)$ to the overall effectiveness of the PAS in the study organizations. It is further revealed that these relationship is significant(at $\mathrm{a}=0.01$ or 0.05 ) Further significant impact of the following PAS Process variables were found on the overall effectiveness of PAS viz PV-2,PV-5,PV-6,PV-7,PV-8,PV-10 and PV-11(Reference: Table II for full version of these variables)

12 It is observed form Tables VIIC to VIIC That PAS Outcome Variables were found to be high and positively correlated $(\mathrm{r} 2=0.886)$ to the overall effectiveness of the PAS in the study organizations. The relationship was found to be significant(at $=0.01$ or 0.05$)$.It is further found that except OV-6 all other PAS outcome variables have significant impact on the overall effectiveness of PAS

(OV-6:Perormance Appraisal System facilitates the growth and Learning of both superiors and subordinates in the organization)

Discussion

It has now been widely realized that in order to have an effective performance appraisal system in the organizations, the system should be made HRD oriented .The effectiveness of a performance appraisal system depends on the extent to which the HRD components are a part of the system (Design and Content Variables ) and how well it is being implemented in the study organizations form the view point of the appraisers and the appraisees .

It was emerged form the study that both the appraisers and appraisees perceived by and large invariably following variables that the (1) Employees have clear understanding of what is expected from them regarding their performance in the organization (DCV-1) (ii) The performance appraisal system provides scope for self appraisal and reflection of the employees (DCV-4)(iii) Employees work thoroughly on self appraisal in terms of reviewing reflecting and analyzing the factors affecting their performance (iv)Employees take part in performance review discussions and (v) HRM/HRD/Personnel Department does follow up work on training needs as identified through appraisals are taken care to a large extent in the study organizations .Such a positive perception is probably due to having self appraisal system by the majority(six out of eight selected organisationsi.e seventy five percent of selected organizations ) of the selected organizations and also due to exercising mechanism of Performance Review discussions by the majority(five out of selected organizations i.e. sixty percent of the selected organizations

Further ,it emerged form the findings that the appraiser's mean score as compared to the appraisee's mean score pertaining to all the variables is higher which means the appraisers, in a sense are marginally more satisfied than the appraisees with the existing performance appraisal system and practices .ahmed's study(1998) which was conducted with reference to two public sector enterprises revealed the same finding but in case of only a few variables Keeping the nature of relevant roles in mind, such a finding may be due comparatively more involvement of the appraisers in the process of designing and implementing the PAS 
The appraisers and appraisees perceived that there does not exists a strong relationships (1) among the Design/Content variables (ii) Among process variables and (iii) among outcome variables which means that various factors affecting the effectiveness of PAS were not being equally taken care of by the employees of study organizations. Further ,it was emerged form the study that the managers (both the appraisers and the appraisees ) perceived that in order to have an effective performance appraisal system,equal weightages is to be given to Design/Content Variables and outcome Variables

Implications

- The findings of the present study clearly indicate that there are variables in all the three categories (viz,Design/content variables ,Process variables and Outcome Variables )which are perceived invariably by both the appraisers and the apprises to be taken care of only to the moderate extent, it is therefore obvious that these variables need special attention of the managers in general and HRD departments of the study organizations in particular so that the same may be taken care of to larger extent in future.fortunately,identification of training needs and career planning and development have been claimed invariably by both the appraisers and the appraisees as the prime objectives of the performance appraisal system. This mutual understanding between the appraisers and the appraisees may be used as momentum in fostering to make continous improvement in the matter as it easier to ensure deep involvement of all the concerned managers in such processes.Ofcourse, a number of variables in all the three categories are being taken of to large extent in the study organization. However the study organizations cannot afford to leave these variables unattended in future. Constant attention,continous review and considerable efforts to take corrective action with full commitment of the top executives is amust.Organisations may be better served by using a combination of different performance improvement measures to capture high performance of its employees .And an improved performance appraisal system regardless of the potential solutions certainly generates necessary support in his direction.

\section{References}

[1] Wexley "Performance Appraisal :An update" research in Personnel and HRM,2:35-79,1984

[2] Srinivasan ,Murali.S "Mangers satisfaction with performance Appraisal system-An Empirical study",FPM Project Report at IIM Ahmedabad,1994

[3] Rudraba savaraj.M.N.’Performance administrative Practices in Indai”,Poona,V.M. publishers,1969

[4] Roberts Gayre E."Performance Appraisals in Fortune 1300",in fimburn,charles.et.al.(ed) Strategic Human Resources Management, New york wiley, 1995

[5] Rao.T.V."Appraising and Developing Managerial Performance", Hyderabad ,academy of Human Resource Management,1992

[6] Rao,T.V. "The HRD Missionary", New Delhi, Oxford and IBH Publishing House, 1990

[7] Murphy ,K.R.; Cleveland;I.M.”Performance Appraisal: An Organizational Perspective “,Boston,Allywn and Bacon,1991

[8] McGregor.D.”An uneasy look at Performance Appraisal "Harvard Business Review,35-:89-94,1957

[9] McCall,M Wand,Devris ,D.L.”Appraisal in Context: Clashing with the Organizational Realities “,Greensbore,NC Centre for creative leadership, 1977

[10] Lourich,N;Bishop,D Hopkins and Yale,"Particapitive Performance Appraisal Effects upon Job Satisfaction Agency Climate and work Values results of quasi experimental Study is Six State Agencies”, Review of Public Personnel Administration ,1(3); 51732,1981

[11] Lisak,R.L.”Procedural Fairness: How Employee Evaluates Procedures"Ph.D Dissertation , university of Iillinois, 1983

[12] Lawler E.E; Mohrman,Allen;ResnikSussan,Performance Appraisal Revisited "Organizational dynamics,13(1);20-35,1984

[13] Laud R.L.'Performance Appraisals in the fortune 1300"in finburn Management, New york, wiley;117,1984

[14] Krishna Usha,Study of Performance Appraisal Practices in selected Indian Enterprises", Unpublished thesis, University of Delhi,1998

[15] Giles and Mossholder,Employee Reactions to Contextual and session Component of Performance Appraisal” Journal of Applied Psychology,75(4);371-377,1990

[16] Fandray,Dayton,"The New thin king in Performance Appraisals",Workforce,p-36-40,2001

[17] Flippo E.b.Personnel Management,Tokyo,Mcgraw Hill Company,1980

[18] Chatterjee ,Leena”Towards an Effective Performance Appraisal System”, Decision 23(1-40169-178,1996

[19] Bernaddin,H.S. and Beatly,R.W. Performance Appraisal: Assessing Human Behavior at work Boston, Kent Publishing Company, 1984

[20] Ahmed,Mufeed S “Performance Appraisal Management”, New delhi anmol publications Pvt Ltd,1998

[21] Jain Ravindra"An Assessment of Effectiveness of Performance Appraisal system in Selected large and Medium Size Manufacturing Organizations ; An Empirical Study ,Abhigyan January-March,2005E 